\title{
Improving Speaking Skills through Cooperative Learning Model Talking Stick Type on Students of Class XI IPS 2 SMA Negeri 7 Singkawang School Year 2015/2016
}

\author{
Dionesia Marisa Ica $^{1)}$, Mardian ${ }^{2)}$, Wahyuni Oktavia ${ }^{3)}$ \\ 1Program Studi Pendidikan Bahasa dan Sastra Indonesia STKIP Singkawang, \\ E-mail:icha_akitson@ymail.com \\ 2Program Studi Pendidikan Bahasa dan Sastra Indonesia STKIP Singkawang, \\ E-mail:mardian@gmail.com \\ 3Program Studi Pendidikan Bahasa dan Sastra Indonesia STKIP Singkawang, \\ E-mail:oktaviawahyuni9@gmail.com
}

\begin{abstract}
This research is motivated by low speech skills, this is due to low student interest and lack of confidence in students and has difficulty in playing the drama. This research is focused on the material to play the drama through Cooperative Type Talking Stick Learning Model. The purpose of this study is to describe the planning, implementation, and results of the Drama through Cooperative Learning Model Type Talking Stick. The formulation of this research problem is how the planning, how the implementation, and how the results of learning activities play the drama through Cooperative Type Talking Stick Learning Model. the method used in this research is descriptive with the form of qualitative and quantitative research. The implementation procedure of this research consists of planning, implementation, observation, and reflection. Research design in the form of Class Action Research. Planning in cycle 1 is good with percentage equal to 74,11\% whereas planning in cycle 2 with percentage $80 \%$. Implementation in cycle 1 first meeting is good with percentage equal to $71,81 \%$ while implementation in cycle 1 second meeting equal to $72,17 \%$. The percentage achieved in cycle 1 overall was $74.54 \%$. Implementation in cycle 2 first meeting Very good with percentage $85.45 \%$, the percentage achieved in cycle 2 second meeting very good with percentage $87,27 \%$. Percentage achieved in cycle 2 overall by $86,36 \%$. Research Result Action Class at cycle 1 with average score reach 69,01 and percentage mastery learn student equal to 53,33\%, themean value in cycle 2 increased become 71,41 with student mastery percentage equal to 83,33\%. Based on this research, it can be concluded that speaking skill in playing drama through Cooperative Learning Model Talking Stick Type is good, it is suggested to teachers especially Indonesian teachers using Cooperative Learning Model Talking Stick Type improves speaking skill especially on play plays material.
\end{abstract}

Keywords: Speaking Skills; Talking Stick; Classroom Action Research

\section{INTRODUCTION}

Speaking is a language skill that develops in a child's life, which is preceded only by listening skills, and at that time the ability to speak or say is studied (Tarigan,2008:3). Given the importance of speaking for high school students then the teacher can not avoid this speaking skill. Speech skills are not skills that can be taught through explanations or explanations. Students will not be skilled in speaking if only speak for no definite purpose.

In relation to Indonesian language and literature learning in Kuriukulum level of educational unit or abbreviated as KTSP, Indonesian language learning is directed to improve the ability to communicate properly and correctly, both orally and in writing. In the KTSP also contained the Competency Standards speak 6. Play the character in 


\section{- -JP-BSI \\ Aurnal Pendidiken Bahasa dan Sastro Indonosi}

the play. Basic Competence 6.1 Conveying dialogue with gestures and mimics, in accordance with character's character.

Based on the results made during the field experience practice (PPL) activities, there are several factors behind the low level of speaking skill among students who are less interested and less motivated in speaking activities because they are not paying attention, the attitude of the students when the talk show looks tense and less relaxed this can be seen from the expression of students who show fear and shame when having to speak in front of the class. These conditions will affect the quality of speech and the students still find it difficult to pronounce the spoken language to be conveyed, and the lack of practice or practice of speaking skills applied in learning.

Based on the above problem, the writer intends to hold an improvement of speech skill through discussion with basic competence, convey dialogue with gestures and mimic, according to character.

Through this research, the writer will hold a renewal to improve the speaking skill through cooperative type talking-type stick model. The reason for choosing a talking stick teaching model is because it is appropriate to apply to speaking learning. Students are required to speak, discuss, and understand what they have read. The specialty of the cooperative type of talking stick model is that students can play while learning by practicing speaking skills. In addition to the sticks and music, they can show the results of speaking skills by expressing what he has read and understood.

The MinimalMasteryCriteria (KKM) determined by SMA Negeri 7 Singkawang Timur is 70. Class XI IPS 1 completeness obtained 73,33\% from 31 students, in class XI IPS 2 mastery reach $41,76 \%$ from 35 students, while in grade XI IPA completeness reached $60 \%$ of 30 students.

Based on the problem, the researcher wanted to do research to improve the students' speaking in class XI IPS 2, especially speaking skill. The reason the author chose to convey dialogue with gestures and mimics, in accordance with the character of the character, because this material relates to activities in expressing their respective opinions about the material to be taught, so this material will attract students so that speaking skills can be improved. The reason the author chose class XI IPS 2 because the results obtained in this class is still low compared with other classes.

\section{RESEARCH METHOD}

The method used in this research plan is adescriptive method. Descriptive means the data decomposes in the form of words or images rather than in the form of numbers. This method is used to provide a clear and detailed description of the data or facts that occurred in the field during the research process took place. This method is used to know about improving the ability to write text speech model through cooperative learning type of stick to the students of class XI IPS 2 SMA Negeri 7 Singkawang Lesson 2015/2016.

Speaking is a means to communicate ideas that are developed and developed according to the needs of the listener and listener(Saddhono, 2012). Speech skills are the ability to pronounce articulation sounds or say words to express, express, convey thoughts, ideas, and feelings (Arsjad, 1993).

The main purpose of talking is to communicate. In order to convey thoughts, ideas and willingness effectively, the speaker should understand the meaning of everything that wants to be communicated (Saddhono, Kundharu, and Slamet, 2012).

Suprijono (2009) states that "Learning by talking stick teaching model encourages students to dare to express an opinion. In implementing learning with the learning model there are several steps as follows.

Cooperative understanding is a learning model that emphasizes learning in heterogeneous groups helping each other, working together to solve problems, and bringing together opinions to gain optimal success both groups and individual cooperative learning (Majid, 2013).Cooperative learning is the ideal solution to the problem of providing opportunities to interact cooperative and not superficial to students from different ethnic backgrounds.

"Cooperative learning is students studying together in small groups of 4-5 students who are equal but heterogeneous, ability, gender, ethnicity/race, and each other help each other with a view to giving opportunity to all students to be actively involved in the thinking process and learning activities " (Trianto, 2007). "Cooperative is an activity that emerges through cooperation will increase motivation far greater than starting an individual competitive environment" (Huda, 2014).

Implementation of learning requires an approach in learning, requires learning methods, and requires a place of execution. The implementation of learning is a process of interaction between trainees and teachers who use all sources in accordance with 


\section{- $-\mathrm{JP}-\mathrm{BSI}$ \\ Iurral Perdidikan Bahasa dan Sastra Indonesia}

the planning that has been prepared previously in order to achieve the goal(Daryanto and Rahardjo, 2012).

The design of this study using classroom action research (PTK) is a scientific activity undertaken by teachers in their class reflects action through several cycles in a collaborative and participatory way that aims to improve or improve the quality of the learning process in class. The study of classroom action research is to obtain practical judgments in concrete situations, therefore the validation of theories or hypotheses derived from the study or research is less dependent on scientific truth tests but on the merits of helping communities to behave more intelligently and skillfully. In this classroom action research, mother NisaWianti acts as a teacher conducting Indonesian language learning, while the researcher acts as an observer. This action research was conducted in class XI IPS 2 SMA Negeri 7 SingkawangTimur. This action research is conducted with at least two cycles, each cycle is carried out with four stages of action planning, action implementation, action observation and action reflection. The research plan is limited by plays the role of drama by using language that is easy to understand.

Techniques and data collection tools are an important part of the research used as a guide on how the author collects data and tools used in collecting the data.

\section{A. Data Collecting Technique}

Data collection techniques in this study are as follows:

- Direct Observation Technique

Observations are conducted by the author by observing the learning process in the classroom. Observations are directed at subject behavior when teachers and students carry out the learning process. Observation is done to know the obstacles, difficulties during the learning process takes place. The tool used is an observation sheet.

- Direct Communication Technique

Communication by conducting interviews that are used to obtain information. Interviews conducted by researchers on teachers and students about the learning process that has been done and how the response or results arising from the learning process. The purpose of this interview is to get as much information as possible.

- Measurement Technique

Communication by conducting interviews that are used to obtain information. Interviews conducted by researchers on teachers and students about the learning process that has been done and how the response or results arising from the learning process. The purpose of this interview is to get as much information as possible.

\section{B. Data Collector Tool}

Data collection tool in this research is test and observation sheet as follows:

1. The observation sheet in the learning process speaks by talking stick.

a. Attitude observation Sheet

Using an attitude observation sheet so that the researcher can observe and record the students' attitudes and behavior during the learning process.

b. Teachers' Assessment Tool (APKG 1) in planning the implementation of cooperative learning type talking stick.

c. Documents, ie tools used as data collectors through literature, recordings or photographs related to the research.

2. Comparative descriptive statistical techniques are used for quantitative data, ie by comparing the results from between cycles. Quantitative data is used to analyze data obtained from speaking test results in expressing an opinion on poetry in the first cycle and the cycle to come. The test results from each cycle will be analyzed using the following calculation steps.

a. Record score obtained by students

b. Calculate the cumulative score of all aspects

c. Calculate the average score

d. Calculate the percentage by the formula. Average valuation formula:

Average Calculate $=$ Amount of All Data Values

Number of Data Values

Rating Criteria:

$\begin{array}{ll}85-100 & =\text { Very Good } \\ 75-84 & =\text { Good } \\ 65-74 & =\text { Adequate } \\ 45-64 & =\text { Less } \\ 0-44 & =\text { Very Less }\end{array}$

3. Critical Analysis Techniques

Critical analysis techniques are used to calculate qualitative data. Qualitative data is used to calculate non-test data in the form of observation sheet. Information description that is analyzed related to student's learning motivation, level of student's understanding of learning, student's view, peer to material, method, media, evaluation used in speech text writing process. Planning of learning implementation is analyzed using APKG 1 format to know the ability of teacher to arrange RPP material plays drama. Implementation of learning is analyzed using 
APKG 2 to know the ability of teachers to implement learning. Students' attitudes during the learning process were analyzed using an attitude assessment format.

\section{RESULT AND DISCUSSION}

Research on improving speaking skill through cooperative type of talking stick model implemented in SMA Negeri 7 Singkawang. The researcher and collaborator, NisaWianti, S.Pd., chose class XI IPS 2 as research object with 35 students consisting of 19 female students and 16 male students. This study was conducted 2 cycles, each cycle consisted of two meetings obtained by increasing the results in each cycle with the following comparison.

- Planning to Improve Speaking Skills through Cooperative Learning Model Talking Stick Type Learning planning that has been compiled from cycle 1 and cycle 2 has increased. The learning planning that has been made has been in accordance with the assessment criteria. Planning the assessment of the results of speech skills activities through cooperative type learning type talk stick obtained through the activities of playing the drama and the role that has been presented.

- Implementation of Speech Skills Activities through Cooperative Learning Model Type Talking Stick

Researchers collaborate with teachers of Indonesian High School 7 State SingkawangNisaWianti, S.Pd., in improving speaking skills. This research is conducted through two cycles consisting of four stages: planning, implementation, observation, and reflection. The implementation of learning is done very well by Indonesian teachers. The impact for students is the ease in understanding the material while improving the work of students.

- The result of speech skill activity through cooperative learning model type talking stick Cycle I

The work can determine the level of ability of students in completing a task. The result of playing the drama through cooperative type of talking stick type model in the first cycle there are still 14 students who still have not reached the Minimum Exhaustiveness Criteria (KKM) that has been established that is 67 while the complete student reaches 16 students, this means success in learning to play the drama on cycle I reached $53.33 \%$. It can be concluded that speaking skill in learning plays drama through cooperative type of talking type stick model in cycle I is included in the category of assessment is good enough, it departs from the percentage before the action that only reached $26,7 \%$. The results of the activities of playing the drama through cooperative type of talking stick teaching model in cycle I include two aspects of assessment, namely process assessment, and result assessment.

- Improved Attitudes of Student Attitudes in Speaking Activities Playing the drama through Cooperative Learning Talking Stick Type

Observation on students' attitude on learning plays drama through cooperative learning type of stick in cycle 1 is conducted to know the success of this strategy implementation in the activity of learning to play the drama. Observation of attitudes are grouped into 3 aspects considered: 1) Active, with good category $48,57 \%$, enough $34,29 \%$, less $17,14 \%$. 2) Cooperation, with goodcategory, reached $54.28 \%$, with enough category reached $28.58 \%$, with category less reach $17,14 \%$. 3) Brave, with good category $48,57 \%$, enough category $37,15 \%$, category less $14,28 \%$. Results achieved cycle 1. $85.71 \%$. Cycle 2 aspects assessed are 1) Active, with good category $53.03 \%$, enough $37.14 \%$, less $2.8 \%$. 2) Cooperation, with goodcategory, reached $51.47 \%$, with enough category reached $28.58 \%$, with category less reach $28.58 \%$. Category less $17.14 \%$ 3) Brave, with good category $44,87 \%$, enough category $25,71 \%$, category less $5,71 \%$ and result reached $88,88 \%$.

- Result of Increased Learning Activity on Speaking Learning Through Model Cooperative Type Talking Stick

Cycle 1 and cycle 2 in the category of good overall and an increase in cycle 1 to $79.68 \%$. And in cycle 2 to $85.71 \%$, an increase of $6.03 \%$.

\section{CONCLUSIONS}

Based on the results of research at SMA 7 Singkawang students' skills in speaking can be concluded that in this study has increased in each cycle, evidenced by several things including as follows. (1) learning plan in cycle 1 reach $74,11 \%$ and in cycle 2 reach $80 \%$ have increase equal to $5,89 \%$. (2) the implementation of learning in cycle 1 reached $74.54 \%$ with good category and in cycle 2 reached $87.27 \%$ with very good category increased by $12.73 \%$. (3) The result in cycle 1 student average is $67,08 \%$ and in cycle 2 reach $72,17 \%$ have increased 5.09\%. 


\section{REFERENCES}

Arsjad, Gmaidar. (1993). Pembinaan Kemampuan Berbicara Bahasa Indonesia. Jakarta: Erlangga.

Daryanto and Muljo Rahardjo. (2012). Model Pembelajaran Inovatif. Yogyakarta: Gava Media.

Huda, Miftahul. (2014). Model-model Pengajaran dan Pembelajaran: Yogyakarta. Pustaka Belajar.

Majid, Abdul. (2013). Strategi Pembelajaran. Bandung: Remaja Rosdakarya.

Saddhono, Kundharu. (2012). Meningkatkan keterampilan Berbahasa Indonesia Teori dan Aplikasi. Bandung: Karya Putra Darwati.

Kundharuand Y. Slamet. (2012). Meningkatkan Keterampilan Berbahasa Indonesia (Teori dan Aplikasi). Yogyakarta: Karya Putri Darwati.

Suprijono, Agus. (2009). Cooperative Learning Teori dan Aplikasi Paikem. Surabaya: Pustaka Pelajar.

Tarigan, Guntur Henry. (2008). Membaca Sebagai Suatu Keterampilan Berbahasa. Bandung: Angkasa Bandung.

Trianto. (2007). Model Pembelajaran Inovatif Berorientasi Konstruktivistik. Jakarta: Prestasi Pustaka. 